\title{
Evolution of local scour downstream of Type A PK weir in non-cohesive sediments
}

\author{
Wyatt D. Lantz ${ }^{1}$, Brian M. Crookston ${ }^{1 *}$, Michele Palermo ${ }^{2}$ \\ ${ }^{1}$ Utah Water Research Laboratory, Department of Civil and Environmental Engineering, Utah State University, 8200 Old Main Hill, Lo- \\ gan, UT 84322-8200, USA. \\ 2 DESTEC-Department of Energy, Systems, Territory and Construction Engineering, University of Pisa, Via Gabba 22, 56122 Pisa, Italy. \\ * Corresponding author. Tel.: +1 435-797-0247. E-mail: brian.crookston@usu.edu
}

\begin{abstract}
A large-scale piano key weir laboratory study was conducted to investigate the evolution of the scour process occurring in the downstream basin for two non-cohesive granular bed materials, including the analysis of scour-hole geometry and patterns at equilibrium. It was observed that hydraulic conditions, particularly tailwater level, significantly affect the scour mechanisms and equilibrium morphology, eventually resulting in scour depths that exceeded the weir height. Unprecedented insights on the scour dynamics are also provided, along with tools to estimate the time evolution and maximum scour depth, its location in the streamwise direction, and the maximum scour length.
\end{abstract}

Keywords: Equilibrium morphology; Granular bed; Piano key weir; Scour evolution.

\section{INTRODUCTION}

Flooding incidents around the globe are occurring with greater frequency and magnitude, resulting in increased impacts on many urban communities. It is estimated that the 100 -year return period floods are occurring at three times the frequency of historical records (Marsooli et al., 2019). For example, three significant flooding events occurred in 2019 (FloodList, 2020) along the Missouri and Mississippi rivers in the U.S with billions of dollars in damage and millions of people directly affected (Center for Disaster Philanthropy, 2019; NWS, 2020). Due to flooding consequences, climate change and population growth, the need for sustainable flood risk management is increasing (Green, 2010).

Flow control structures commonly used in channels and for flood-protection schemes include dams and levees, spillways, and various types of gates and weirs. Some inherited structures ( $>50$ years old) that do not meet current hydraulic design criteria and/or have other safety deficiencies are being rehabilitated. To this end, labyrinth or piano key weirs (PK weir) are regularly considered due to hydraulic efficiency, compact footprint, techno-economical viability, and passive flow control nature (Crookston et al., 2019; López-Soto et al., 2016; Machiels et al., 2014). For the PK weir, flow passes over the entire crest length with the majority of flow collected in the outlet keys, producing a stronger inclined jet compared to the falling nappe. However, local scour at these weirs and other hydraulic structures remains a challenging task because the scour mechanism is affected by many parameters, including local geological and hydrological conditions, structure geometry, and the threephase nature of the flow (Ben Meftah and Mossa, 2020; Bombardelli et al., 2018; Bormann and Julien, 1991; Ettema et al., 2004; Hoffmans and Verheij, 1997; Lantz et al., 2020).

Scour at the downstream base of weir-like structures such as labyrinth and PK weirs, ogee weirs, broad-crested weirs, rock weirs, and similar grade control structures can be considered as jet-induced processes (Aderibigbe and Rajaratnam, 1998), which can be classified as two major types: 1) plunging jets or 2) submerged jets (Hoffmans and Verheij, 1997; Jia et al.,
2001). Plunging jet scour has been extensively researched for a variety of hydraulic structures (e.g., flip bucket spillways, lowlevel outlets, grade control structures, linear weirs, etc.). The shape and characteristics of plunging jets can take many forms such as cylindrical jets, angled ramp jets (ranging from vertical to horizontal), and free fall jets (e.g., Adduce and Sciortino, 2006; Bombardelli et al., 2018; Dey and Raikar, 2007; Mason and Arumugam, 1985; Pagliara et al., 2008a; Palermo et al., 2018) (of these forms, angled ramp jets and free fall jets apply to PK weirs, with the former having much more potential to generate scour). Additionally, for various weir types the analysis of scour evolution and scour features at equilibrium enhanced the understanding of the physics of the problem and allowed practitioners to design scour protection measures (Ben Meftah and Mossa, 2020; Bormann and Julien, 1991; Chen et al., 2016; Kuhnle et al., 2002; Mason and Arumugam, 1985; Nasrollahi et al., 2008; Pagliara et al., 2008b; Schoklitsch, 1932; Stein et al., 1993; Wang et al., 2019). Hence, previous studies reveal that structure configuration and hydraulic conditions significantly affect equilibrium morphology including general scour patterns and temporal evolution, maximum scour depth $\left(Z_{\max }\right)$, maximum scour depth location in the streamwise direction $\left(X_{\max }\right)$, and maximum scour hole length $\left(L_{\max }\right)$.

Currently, limited research has been published on local scour at nonlinear weirs. Upstream siltation and sediment removal for PK and labyrinth weirs were investigated by Gebhardt et al. (2019) and Noseda et al. (2019). Gebhardt et al. (2019) concluded that the shape of the labyrinth weir produces a horseshoe-vortex in the inlet key causing sediment transport. Noseda et al. (2019) found that upstream scour can exceed the weir height $(P)$. Elnikhely and Fathy (2020) proposed a prediction method for various apex angles for triangular labyrinth weirs with a downstream apron. They showed that labyrinth weirs produce less scour in comparison to linear weirs. In particular, the least amount of scour downstream of the apron was found to occur in the presence of labyrinth weirs with a sidewall angle $(\alpha)$ of $60^{\circ}$. Yazdi et al. (2021) studied scour downstream of both rectangular and triangular PK weir geometries with the weir height, $P$ of $0.15 \mathrm{~m}$ and $0.20 \mathrm{~m}$ for a non-cohesive gravel 
with a median gravel size, $d_{50}=7.8 \mathrm{~mm}$. They presented prediction methods to estimate $Z_{\max }, X_{\max }$ and $L_{\max }$ for both weir geometries, indicating that triangular PK weirs produce less scour on average than rectangular PK weirs. Palermo et al. (2020) evaluated equilibrium morphology at PK weirs and analyzed the scour mechanisms that produce bed formations downstream. Jüstrich et al. (2016) and companion study Pfister et al. (2017) analyzed riverbed scour at PK weirs and provided tools to estimate $Z_{\max }, X_{\max }$, and $L_{\max }$. Furthermore, Jüstrich et al. (2016) presented a comprehensive comparison of PK weir scour data to scour formulas pertaining to other structures. Pfister et al. (2017) focused on scour mitigation at PK weirs using rip rap protection. To this end, the authors adopted the relationships developed by Jüstrich et al. (2016) to predict scour geometry. Despite these recent advancements, the scour evolution has never been taken into consideration. Likewise, there is a lack of knowledge about potential scale effect and influence of sediment gradation.

Therefore, a large-scale $(P=0.42 \mathrm{~m})(88 \%$ of all constructed PK weirs have $1 \mathrm{~m} \leq P \leq 6 \mathrm{~m})$ physical model study was conducted with a Type A PK weir geometry and two non-cohesive gravels for a range of hydraulic conditions. Results include jet characteristics generated by the PK weir, analysis of scour development as a function of time, and evaluation of main scour parameters at equilibrium. It does not escape the authors' attention that further analyses are needed to provide a first principles-based method allowing designers to predict scour geometry regardless of the hydraulic conditions and structure characteristics.

\section{MATERIAL AND METHODS}

This study was conducted at the Utah Water Research Laboratory at Utah State University in a rectangular flume, 2-meter wide, 1.8-meter deep, and 16-meter long. Fig. 1 shows the experimental setup, with $H$ indicating upstream total head ( $H=h_{u}+V^{2} / 2 g$ ) where $h_{u}$ is the piezometric or depth of flow relative to the weir crest (with total weir crest length $=L_{c}$ ), $g$ is acceleration due to gravity, and $V$ is the average approach velocity. Also shown in Fig. 1 is the PK weir foundation height $P_{d}$, the change in energy head, $\Delta H$, and key scour dimensions including $Z$, scour depth, $X$ scour depth location along x-axis, $L$ the length of scour, and the corresponding time for these parameters, $t$. Maximum values are noted with the subscript max. The headbox for the flume featured a diffuser and rock baffle to provide quasi-uniform flows $(Q)$ (water temperatures ranged from about $5-10{ }^{\circ} \mathrm{C}$ ) to the flat crest PK weir. Tailwater depth $\left(h_{d}\right)$ was controlled with a stop log assembly. The mobile bed section of the flume began with $z=0 \mathrm{~m}$ and $x=0 \mathrm{~m}$ at the bottom and downstream face of the PK weir (see Fig. 1), with $z$ positive in the direction of scour and $x$ positive in the stream- wise direction. The mobile bed was $1.09 \mathrm{~m}$ deep and featured a clear acrylic panel for monitoring scour evolution. Plan and side views of the adopted PK weir geometry are shown in Fig. 2 and summarized in Table 1, where $W_{u}$ is a PK weir unit with, $W_{i}$ and $W_{o}$ are inlet and outlet unit widths, respectively. $B$ is the depth of the PK weir, $B_{b}$ is the depth of the PK weir base, $B_{i}$ and $B_{o}$ are the inlet and outlet key overhang depths, respectively. The PK weir wall thickness is $t_{s} ; S_{i}$ and $S_{o}$ are the slopes of the inlet and outlet keys, respectively, $N$ is the number of PK weir keys or cycles, and the distance from the downstream PK weir base to monitoring locations is noted as $x_{m 1}, x_{m 2}$, and $x_{m 3}$.

The study was performed with two types of substrate. Both substrate types were angular, non-cohesive gravel, but of varying granulometric properties (Table 2) where $d_{90}=$ diameter for which $90 \%$ of material is finer, $d_{50}=$ median gravel size, coefficient of gradation $\sigma=\left(d_{84} / d_{16}\right)^{1 / 2}$, and $G=\rho_{s} / \rho$ substrate specific density, with $\rho_{s}=$ sediment density and $\rho=$ water density. Furthermore, tested bed materials were poorly (Substrate 1) or uniformly (Substrate 2) graded. The results of this study are limited to the materials tested; however, according to Annandale (1995) material properties can be scaled between the laboratory and field applications (e.g., by using the Erodibility Index Method).

For each laboratory test, the gravel substrate material was prepared by uniformly adding gravel and raking until a planar bed was achieved that is level with the base of the PK weir (for which was assumed $z=0 \mathrm{~m}$, see Fig. 1). No additional compaction of the material was performed. Any material deposited downstream of the scour hole during a test was not manually removed, thus any bedforms were allowed to form and evolve and the results are more applicative to field conditions where river sediments would be deposited adjacent to the scour hole, not transported further downstream.

Discharge was measured by using a calibrated (ASTM standards) venturi meter ( $\pm 0.25 \%$ accuracy). Water levels were measured with a stilling well and point gage $( \pm 1.5 \mathrm{~mm}$ precise $)$.

Table 1. Geometric parameters of the PK weir.

\begin{tabular}{ll}
\hline Parameter & Value \\
\hline$B$ & $1.04 \mathrm{~m}$ \\
$B_{b}$ & $0.52 \mathrm{~m}$ \\
$S_{o}=S_{i}$ & 0.55 \\
$W_{u}$ & $0.49 \mathrm{~m}$ \\
$N$ & 4.00 \\
$P$ & $0.42 \mathrm{~m}$ \\
$t_{s}$ & $0.025 \mathrm{~m}$ \\
$W_{i} / W_{o}$ & 1.28 \\
$P_{d}$ & $1.09 \mathrm{~m}$ \\
\hline
\end{tabular}

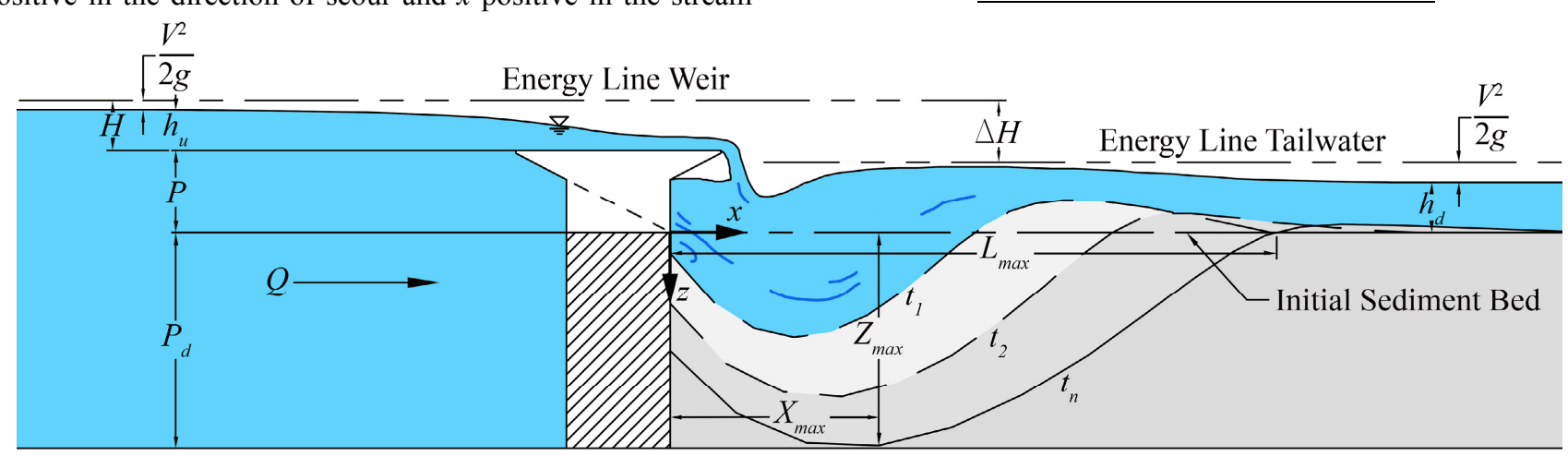

Fig. 1. Side view of the experimental setup including PK weir and scour morphology. 
Table 2. Granulometric properties of bed materials.

\begin{tabular}{lcc}
\hline & Substrate 1 & Substrate 2 \\
\hline$d_{90}(\mathrm{~mm})$ & 20.00 & 9.10 \\
$d_{50}(\mathrm{~mm})$ & 13.00 & 6.50 \\
$\sigma$ & 1.54 & 1.30 \\
$\rho_{s}\left(\mathrm{~kg} / \mathrm{m}^{3}\right)$ & 2,604 & 2,646 \\
$G$ & 2.61 & 2.65 \\
\hline
\end{tabular}

According to Zhang et al. (2018), the downstream tailwater elevation was measured at two locations within the flume using ultrasonic sensors (Microsonic mic+130/IU/TC; Microsonic, 2021) ( $\pm 1 \%$ accuracy) and a temporal average was used to compute $h_{d}$.

Scour morphology was captured using two techniques. First, a grid was attached to the acrylic surface to monitor scour evolution at the wall using a high-resolution camera (GoPro HERO7 Black, 4K resolution) a sufficient distance from the window to minimize distortion of digital video and photos during tests. However, measurements made at the window do not account for the slight three-dimensionality of the scour formation occurring under certain hydraulic conditions. To overcome this issue and provide more accurate measurements of the maximum scour depth, columns of small spheres $(G=$ 0.53 ) (sphere diameter $=40 \mathrm{~mm}, 10$ spheres per column at $0.1 \mathrm{~m}$ spacing) were buried in the substrate. Spheres were positioned at monitoring locations (Fig. 2b), that were preliminary selected to be representative of the zones of the bed where maximum scour depth could be expected to occur. Namely, monitoring locations 1,2 and 3 were positioned just downstream of the outlet keys, whereas monitoring locations 4 , 5 and 6 were selected in order to account for the threedimensionality of the scour hole, especially at higher discharge rates. As scour evolved and material was removed, a buoyant sphere would then be exposed and at about $50 \%$ exposure, it would be released and rise to the surface to mark that depth and location. Sphere depth locations were color-coded, and any sphere surfacing was documented with video recordings. To avoid premature removal of the spheres prior to being uncovered, the specific weight and hence buoyancy of the spheres was controlled (Fig. 3) by filling a portion of the sphere with silicone. This proved to be an excellent technique to mark scour morphology at specific locations across the PK weir.

According to Bung et al. (2021), an Intel ${ }^{\circledR}$ RealSense $^{\mathrm{TM}}$ D435 depth camera was used to survey the downstream bed topography at equilibrium $( \pm 1.0 \mathrm{~mm}$ accuracy operated within $0.6 \mathrm{~m}$ and $0.8 \mathrm{~m}$ range). This camera includes active stereoscopy via two infrared cameras and an RGB camera. Camera scans were verified by taking vertical point measurements on a grid with a point gage $( \pm 1 \mathrm{~mm})$ mounted to a flume carriage. a.)

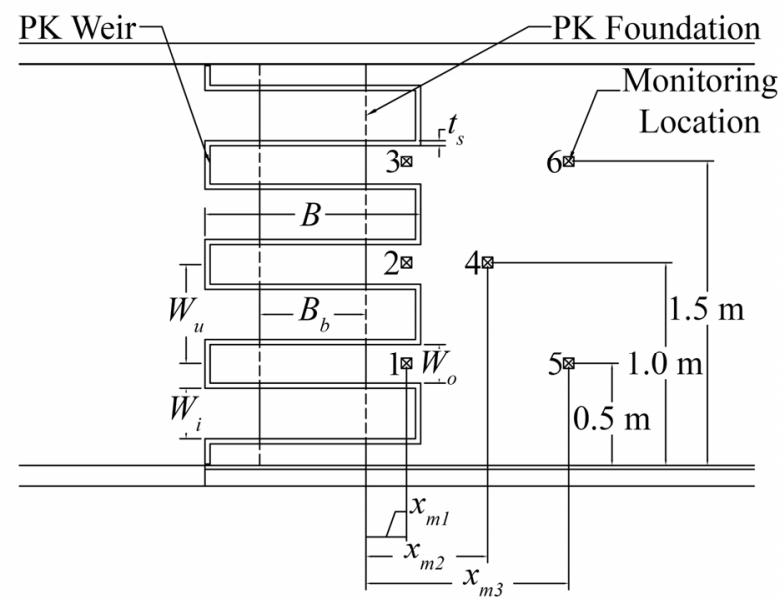

b.)

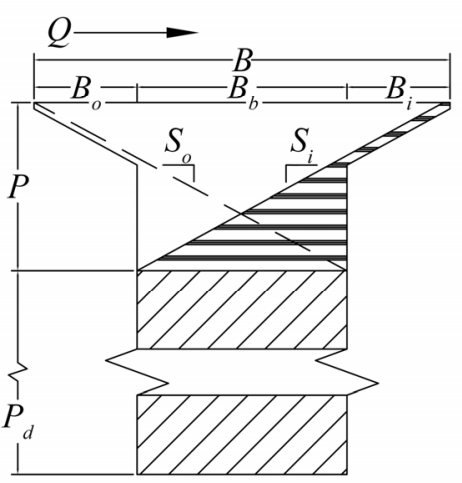

Fig. 2. Geometric and hydraulic parameters of this study in plan (a) and in profile (b).

The infrared camera was operated with a global shutter and $3 \mu \mathrm{m} \times 3 \mu \mathrm{m}$ pixel size. The depth properties include a field of view (FOV) $86^{\circ} \times 57^{\circ}\left( \pm 3^{\circ}\right)$ and a max output resolution of 1280 $\times 720$ pixels. The RGB camera properties included a rolling shutter, a max resolution of $1920 \times 1080$ pixels, an FOV of $64^{\circ} \times$ $41^{\circ} \times 77^{\circ}\left( \pm 3^{\circ}\right)$. Additional camera details are provided in Lantz (2021). A MATLAB script was developed for post processing to gather various scour dimensions and prepare various plots of two-dimensional and three-dimensional scour profiles.

Test conditions are summarized in Table 3, which includes $Q, h_{d}$, and the headwater ratio $H / P$ for both the substrate materials. Note that some tests were repeated in order to validate the experimental methodology (Table 4). The minimum tested $h_{d}$ depended on the value of $Q$. Tailwater measurements were taken $4.75 \mathrm{~m}$ downstream of the weir. It was observed that when gravels were deposited downstream of the scour hole, this dune had negligible effect on the $h_{d}$ condition at the point of measurement.
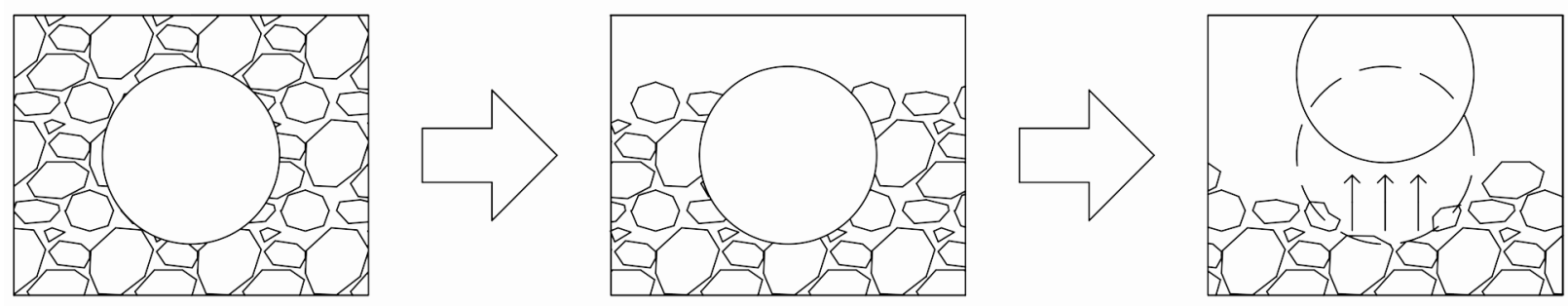

Fig. 3. Diagram sketch illustrating different phases of sphere ejection. 


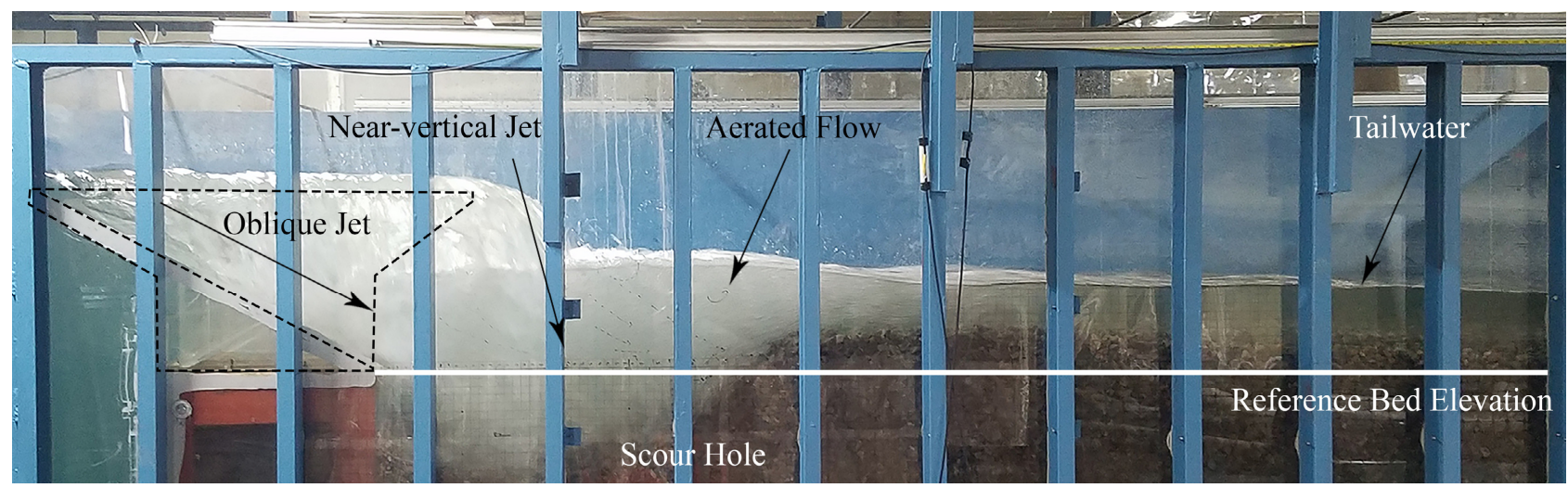

Fig. 4. Side view of three-dimensional jet patterns originating from PK weir.

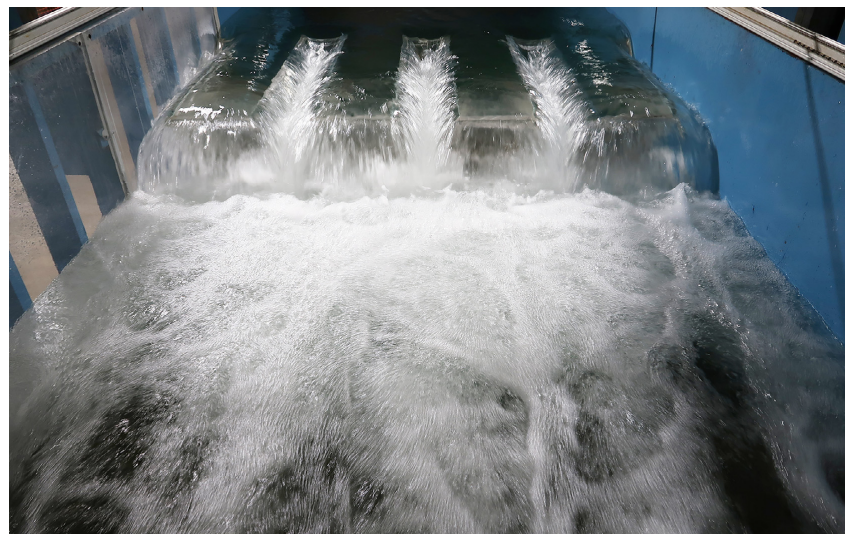

Fig. 5. Top view of flow features at PK weir crest and downstream region.

Table 3. Summary of tested conditions.

\begin{tabular}{|c|c|c|c|}
\hline Substrates & $\begin{array}{l}\text { Discharge, } \\
Q\end{array}$ & $\begin{array}{c}\text { Headwater Ratio, } \\
H / P\end{array}$ & $\begin{array}{c}\text { Tailwater Depth, } \\
h_{d}\end{array}$ \\
\hline \multirow{9}{*}{1 and 2} & \multirow{3}{*}{$0.15 \mathrm{~m}^{3} / \mathrm{s}$} & \multirow{3}{*}{0.11} & $0.16 \mathrm{~m}$ \\
\hline & & & $0.26 \mathrm{~m}$ \\
\hline & & & $0.42 \mathrm{~m}$ \\
\hline & \multirow{3}{*}{$0.30 \mathrm{~m}^{3} / \mathrm{s}$} & \multirow{3}{*}{0.18} & $0.17 \mathrm{~m}$ \\
\hline & & & $0.25 \mathrm{~m}$ \\
\hline & & & $0.43 \mathrm{~m}$ \\
\hline & \multirow{3}{*}{$0.60 \mathrm{~m}^{3} / \mathrm{s}$} & \multirow{3}{*}{0.35} & $0.22 \mathrm{~m}$ \\
\hline & & & $0.28 \mathrm{~m}$ \\
\hline & & & $0.43 \mathrm{~m}$ \\
\hline
\end{tabular}

To avoid any bed modification or pre-scour during the setup of test conditions, the flume was slowly filled until a tailwater depth $h_{d} \approx 0.42 \mathrm{~m}$ was achieved. Discharge was then increased and the tailwater was lowered to the target $h_{d}$. Once the target tailwater level was reached, the experiment began with timer and video recordings. Throughout the duration of each test, scour evolution was monitored. Nonetheless, considering that the kinetics of the scour process is faster at the beginning of the test, observation frequency was high (taken every 30-60 s) until the rate of scour reduced and then observation frequency could also be reduced (typically after 30 minutes). For all tests, equilibrium configuration was achieved. Notably, tests with the highest $Q$ and lowest $h_{d}$ combinations lasted up to $t=18 \mathrm{hrs}$ or longer, whereas equilibrium (i.e., time to equilibrium $=t_{e}$ ) was reached for $t<3 \mathrm{hrs}$ for low $Q$ and highest $h_{d}$. According to Hoffmans and Verheij (1997), the equilibrium condition was considered to be achieved and defined as less than $5 \%$ change in all scour hole geometry parameters. However, for most tests, the difference between the last two bed measurements were less than $1 \%$.

\section{RESULTS AND DISCUSSION PK weir hydraulics}

Unique scour patterns were observed downstream of the PK weir due to the jets originating from the structure. Because of the structure geometry, the flow was not uniformly distributed along the transverse direction. Notably, most of the flow is discharged via the outlet keys. As a consequence, sub-vertical jets, having the inclination $S_{o}$, enter the downstream water body resulting in a confined vortex formation (Fig. 4). Conversely, the inlet keys of the PK weir are characterized by a reduced unit discharge and produced a near-vertical jet (Figs. 4 and 5). Considering that the jet power is an increasing monotonic function of the unit discharge, $q,\left(\mathrm{~m}^{2} / \mathrm{s}\right)$ computed as $Q / W$ for the case of a PK weir where $W$ is the width of the flume, and that the shear stress acting on the bed material scales with the jet power, the resulting equilibrium morphology exhibits threedimensional features with maximum scour depths $Z_{\max }$ corresponding with the outlet keys. In addition, the nature of the impinging flow is essentially two-phasic. Note that as flows passed over the PK weir, air was entrained across the entire weir width resulting in localize flow bulking. Nonetheless, according to Ervine et al. (1997), the presence of air in the impinging jet depended on the travelling distance. Thus, for higher tailwater depths, black water conditions would eventually occur for plunging jets.

\section{Scour evolution}

The impinging jets from the PK weir produced a local scour hole that increased in depth $Z$ and length $L$ with time $t$ until asymptotically reaching equilibrium. Scour-hole evolution was observed to occur during three main phases (Fig. 6). During the initial phase (Fig. 6A), shear stresses on the material significantly exceeded the critical shear stress resulting in a rapid and significant displacement and transport of bed particles. In this phase, the presence of a confined vortex contributes to partially keeping in suspension/rotation the scoured bed material within the scour hole. Consequently, scour mainly enlarges in the vertical direction because of the flow confinement, the reduced diffusion length and the significant vertical component of the resulting force acting on the water surface (obtained by applying the linear momentum equation). Conversely, the effect of the horizontal component of the resulting force acting on the bed material becomes more significant with the diffusion length, as the jet impact angle on the scour surface reduces (Bormann and Julien, 1991). Therefore, the kinetics of the bed material streamwise transport increases resulting in the longitudinal extension of the scour hole and in a frontal dune formation. 

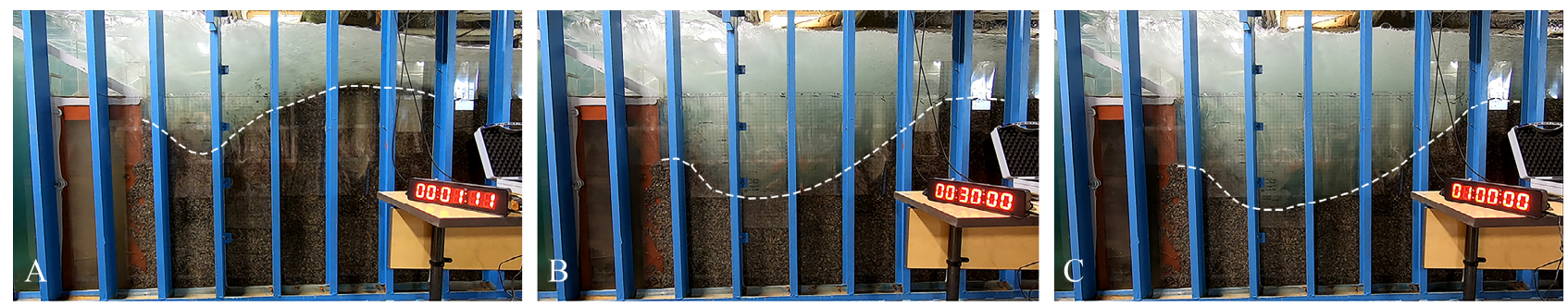

Fig. 6. Scour development with time for (A) Initial Phase, (B) Second Phase, and (C) Final Phase.

Table 4. Maximum scour parameters from each experimental run.

\begin{tabular}{|c|c|c|c|c|c|c|c|c|}
\hline $\begin{array}{l}\text { Run } \\
\#\end{array}$ & Substrates & $\begin{array}{l}t \\
(\min )\end{array}$ & $\begin{array}{l}Q \\
(\mathrm{~L} / \mathrm{s})\end{array}$ & $\begin{array}{l}h_{d} \\
(\mathrm{~m})\end{array}$ & $\begin{array}{l}Z_{\max } \\
(\mathrm{m})\end{array}$ & $\begin{array}{l}X_{\max } \\
(\mathrm{m})\end{array}$ & $\begin{array}{l}L_{\max } \\
(\mathrm{m})\end{array}$ & $\begin{array}{l}\forall \\
\left(\mathrm{m}^{3}\right)\end{array}$ \\
\hline 1 & \multirow{12}{*}{ 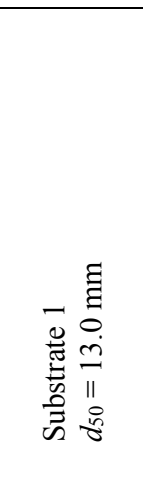 } & 180 & 150 & 0.16 & 0.18 & 0.21 & 0.61 & 0.12 \\
\hline 2 & & 180 & 150 & 0.26 & 0.04 & 0.07 & 0.50 & 0.02 \\
\hline $3 *$ & & 0 & 150 & 0.42 & No Scour & & & \\
\hline 4 & & 240 & 300 & 0.21 & 0.36 & 0.48 & 1.07 & 0.42 \\
\hline $4 \mathrm{R}$ & & 480 & 300 & 0.17 & 0.33 & 0.42 & 1.04 & 0.36 \\
\hline 5 & & 180 & 300 & 0.25 & 0.26 & 0.38 & 0.82 & 0.22 \\
\hline 6 & & 180 & 300 & 0.43 & 0.09 & 0.21 & 0.42 & 0.03 \\
\hline 7 & & 1200 & 600 & 0.23 & 0.83 & 0.89 & 2.99 & 1.98 \\
\hline $7 \mathrm{R}$ & & 900 & 600 & 0.22 & 0.71 & 0.69 & 2.20 & 1.49 \\
\hline 8 & & 960 & 600 & 0.28 & 0.68 & 0.71 & 1.97 & 1.22 \\
\hline $8 \mathrm{R}$ & & 900 & 600 & 0.29 & 0.63 & 0.70 & 1.80 & 1.11 \\
\hline 9 & & 300 & 600 & 0.43 & 0.41 & 0.62 & 1.28 & 0.57 \\
\hline 10 & \multirow{10}{*}{ 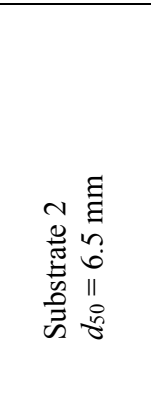 } & 450 & 150 & 0.10 & 0.28 & 0.40 & 1.07 & 0.39 \\
\hline 11 & & 240 & 150 & 0.27 & 0.11 & 0.16 & 0.51 & 0.04 \\
\hline $12 *$ & & 0 & 150 & 0.43 & No Scour & & & \\
\hline 13 & & 1050 & 300 & 0.14 & 0.56 & 0.52 & 1.81 & 1.03 \\
\hline 14 & & 900 & 300 & 0.25 & 0.36 & 0.49 & 1.16 & 0.50 \\
\hline 15 & & 840 & 300 & 0.42 & 0.27 & 0.39 & 0.74 & 0.19 \\
\hline 16 & & 1380 & 600 & 0.25 & 1.06 & 0.99 & 3.35 & 3.61 \\
\hline $16 \mathrm{R}$ & & 1170 & 600 & 0.22 & 1.01 & 1.00 & 3.19 & 3.36 \\
\hline 17 & & 960 & 600 & 0.28 & 0.99 & 1.04 & 3.43 & 3.14 \\
\hline 18 & & 1020 & 600 & 0.43 & 0.68 & 0.89 & 2.04 & 1.38 \\
\hline
\end{tabular}

*No scour observed

The duration of this first phase depends on the deflection of the jet caused by hydraulic conditions (i.e., it depends on $Q$ and $h_{d}$ ) and the scour surface is characterized by an inclination that is higher than the wet angle of repose of the bed material. Notably, it was observed that this initial phase is similar to that occurring for vertical and sub-vertical plunging jets (Bombardelli et al., 2018).

Following this first phase the scour hole evolved both in the streamwise and vertical directions although scour in the vertical direction continued at a relatively slower rate. This second phase (Fig. 6B) includes the downstream migration of $Z_{\max }$ because of the increased diffusion length and the consequent jet deflection. During this phase, the inclination of the scour surface from the horizontal becomes almost equal to the wet angle of repose of the bed material, thus corroborating the findings of previous studies on other grade-control structures (e.g., Bormann and Julien, 1991; Hoffmans, 1998). The bed load transport exhibits periodical inversions of direction. Namely, groups of particles slid from the side towards the bottom of the scour hole and then were transported out by the impinging flow. This behavior was observed previously by Pagliara et al. (2008c) in scour processes occurring downstream of block ramps, especially for non-uniform bed materials.
The final and third phase of scour evolution (see Fig. 6C) was characterized by no additional vertical scour ( $Z_{\max }$ reached) and a slight longitudinal expansion of the scour hole up to equilibrium. Namely, additional armoring of the scour hole was observed during this phase with the smallest particles either transported beyond the movable bed or deposited immediately downstream of the scour hole (Hoffmans and Verheij, 1997). Overall, the scour mechanism occurring during the second and third phase can be encompassed by the developed phase as defined in Bombardelli et al. (2018).

Furthermore, the analysis of scour evolution allowed the identification of interesting features pertaining to the sediment gradation of the superficial layer of the scour hole at static equilibrium (i.e., when the flow action ceases). In Fig. 7, the original granulometric curve of the bed material is contrasted with those obtained at different cross-sections located upstream of and in correspondence with $Z_{\max }$. Such analysis represents an unprecedented result for this structure typology and highlights that for Substrate 2, there is not a significant spatial variation of the granulometric characteristics of the material. Conversely, for coarser (and non-uniform) bed materials (Substrate 1), a granulometric sorting process occurs. Namely, close to the section of maximum scour depth, bed material becomes 

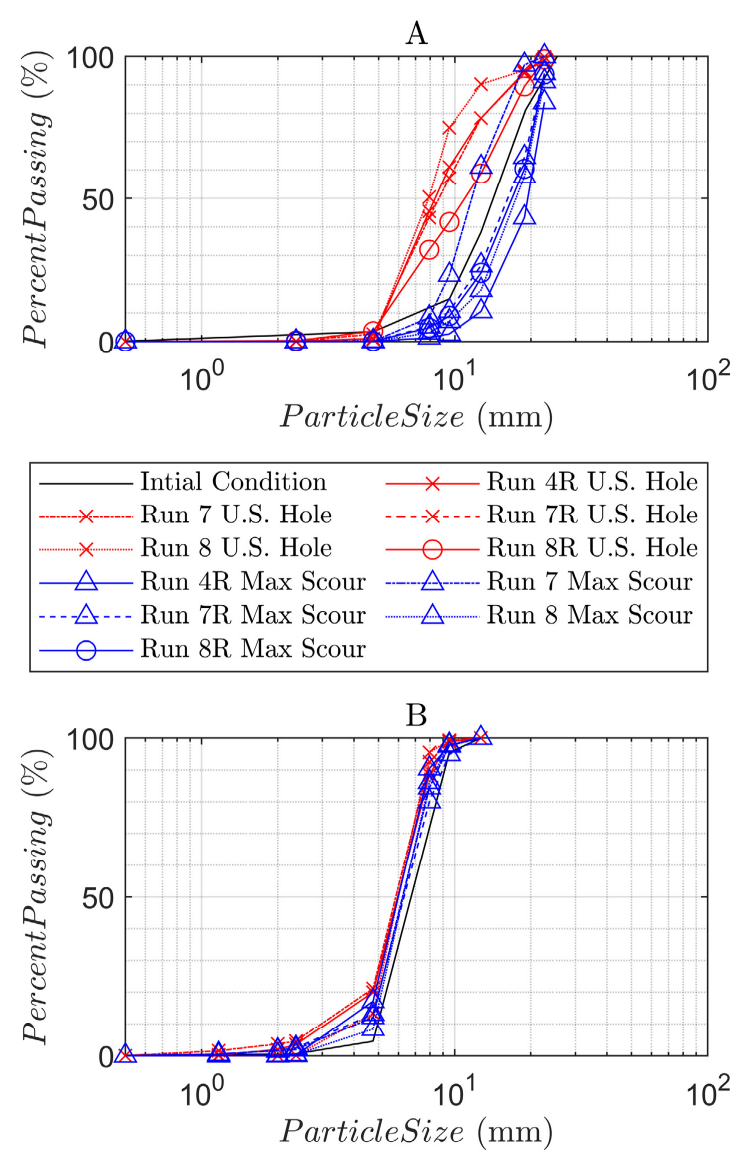

\begin{tabular}{|c|c|}
\hline $\begin{array}{c}- \text { Intial Condition } \\
\times \quad \text { Run } 16 \text { U.S. Hole } \\
\times \quad \text { Run } 17 \text { U.S. Hole } \\
\triangle \quad \text { Run } 16 \text { Max Scour } \\
\triangle \quad \text { Run } 17 \text { Max Scour }\end{array}$ & $\begin{array}{c}\times × \text { Run } 13 \text { U.S. Hole } \\
-\times-- \text { Run 16R U.S. Hole } \\
\triangle \triangle \text { Run 13 Max Scour } \\
--\triangle-- \text { Run 16R Max Scour }\end{array}$ \\
\hline
\end{tabular}

Fig. 7. Sieve analysis of the equilibrium superficial layer of the scour hole at selected locations in the scour hole upstream of and at the location of maximum scour depth $\left(Z_{\max }\right)$ for $(\mathrm{A})$ substrate 1 and (B) substrate 2 .

more uniform and is characterized by a much larger mean diameter (approximately equal to the $d_{90}$ of the original mixture). In the upstream part of the scour hole, an overall reduction of the median diameter $d_{50}$ occurs, resulting in an increase of the material non-uniformity. This occurrence corroborates the findings of Hoffmans (1998), who indicated that it is more

A

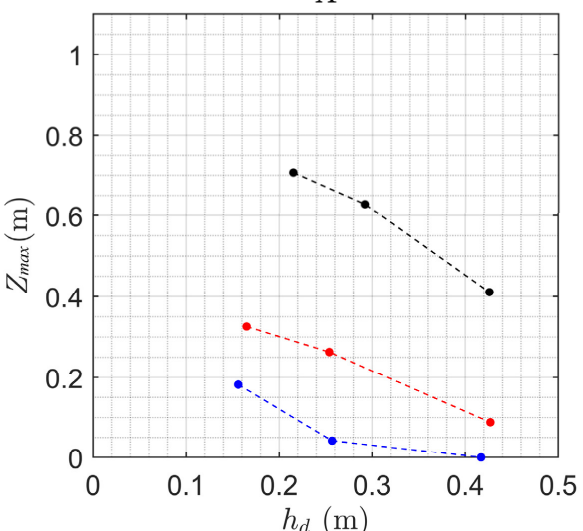

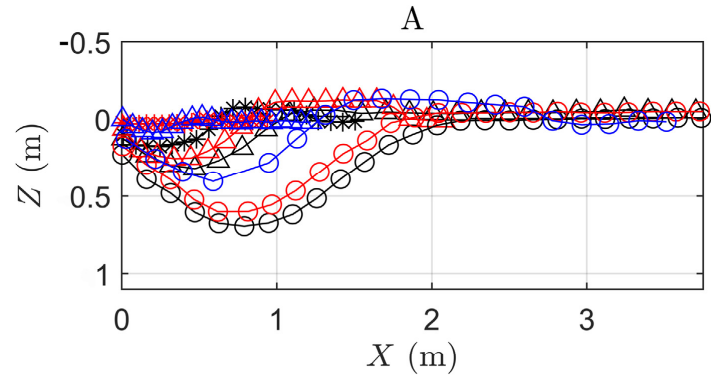

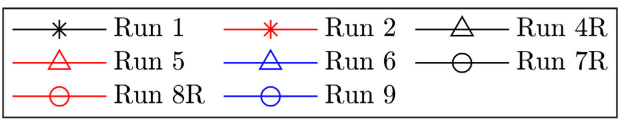

$\mathrm{B}$

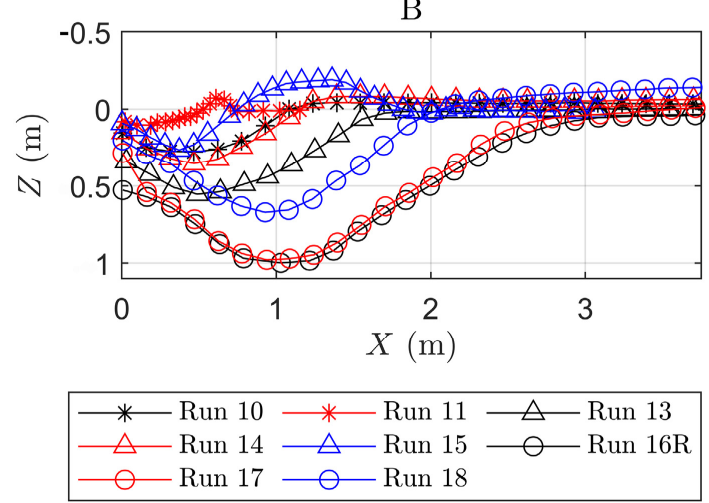

Fig. 8. Maximum longitudinal scour profiles for (A) Substrate 2 and (B) Substrate 1.

appropriate to assume $d_{90}$ instead of $d_{50}$ for scour prediction formulas. In addition, similar observations were also made by Pagliara et al. (2008c), who analyzed the granulometric characteristics of the superficial layer of the scour formation occurring downstream of block ramps for both uniform and non-uniform bed materials. They concluded that the variation in granulometric characteristics of the superficial layer is essentially caused by the division of the flow occurring in correspondence with the section of maximum scour depth. More specifically, depending on the inclination of the jet entering the water surface, finer particles are transported both upstream and downstream of the section of maximum scour depth. However, those grains transported upstream remain within the scour hole, thus increasing the non-uniformity of the superficial layer at static equilibrium.

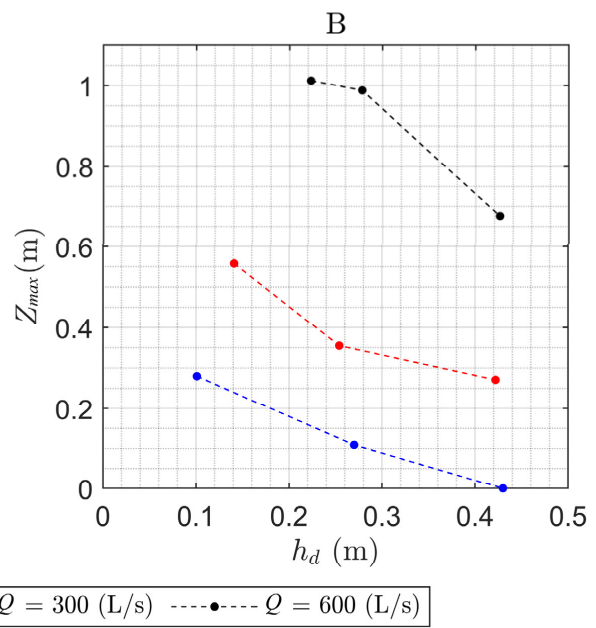

Fig. 9. $Z_{\max }$ as function of $h_{d}$ for different $Q$ and (A) Substrate 2 and (B) Substrate 1 . 
In the tested range of parameters, Substrate 1 took up to 14 hours to reach equilibrium, i.e., much less than the average time required by the coarser Substrate 2 under identical conditions (Table 4). In addition, $Z_{\max }$ was greater for Substrate 1. Namely, Figs. 8A and 8B show the maximum longitudinal profiles for tests pertaining to Substrate 1 and 2, respectively. Likewise, Figs. 9A and 9B evidence the effect of $h_{d}$ on $Z_{\max }$. Notably, these results corroborate the findings of Dey and Sarkar (2006), who analyzed the effect of sediment gradation on scour occurring downstream of an apron.

However, $h_{d}$ also affects the kinetics of scour evolution. Note that such behavior was also pointed out for bridge scour. Based on the approach developed by Oliveto and Hager (2002), Palermo et al. (2021) proposed the following functional governing equation for scour evolution at symmetric bridge piers:

$$
\frac{Z_{t}}{Z_{\max }}=f(\xi, T)
$$

where $Z_{t}=$ scour depth at time $t, \xi$ is the temporal scour evolution parameter (depending on $h_{d} / P$, see Palermo et al. 2021) and $T$ is the non-dimensional time presented as Eq. (1b) for PK weirs:

$$
T=\frac{t}{L_{c}}\left[g d_{90} \frac{\left(\rho_{S}-\rho\right)}{\rho}\right]^{0.5}
$$

and furthermore, Pagliara et al. (2008b) showed that Eqs. (1a) and (1b) are also suitable to represent the evolution of all jetdriven scour problems. Therefore, based on experimental evidence, in the following, Eq. (1a) may be specialized for PK weirs.

To this end, first considered is the evolution data pertaining to the longitudinal scour section in correspondence with the acrylic wall or viewing window. In so doing, the values of $Z_{t} / Z_{\max }$ are juxtaposed to $T$ and $\log (T)$. It was found that the duration of the initial phase (in which most of the scour depth occurs) decreases with $h_{d}$ and evolution exhibits a linear behavior in a semi-logarithmic scale, as expected according to literature noted above. Figs. 10 and 11 show $Z_{t} / Z_{\max }$ vs $(T)$ and $\log (T)$ for selected tests pertaining to Substrate 1 (tests $7 \mathrm{R}, 8 \mathrm{R}$, and 9) and Substrate 2 (tests 13, 14, and 15).

Following this evidence, PK weir scour evolution can be predicted using Eqs. (2a) and (2b):

$\frac{Z_{t}}{Z_{\max }}=0.3(\xi \log (T))+0.39$

$\xi=-0.2\left(\frac{h_{d}}{P}\right)+0.81$

valid for $0.02 \leq \log (T) \leq 3.5$ and $0.24 \leq h_{d} / P \leq 1.03$. Fig. 12 illustrates scour evolution data pertaining to all tests. The good predicting capability of the proposed Eq. (2) is also shown in Fig. 13, where measured values of the variable $Z_{t} / Z_{\max }$ are contrasted against the counterpart calculated using the mentioned relationship.

It is worth noting that a higher deviation was found to occur for scour depths measured during the first few minutes of the process, which is consistent with other scour-related problems (e.g., Pagliara et al., 2008b).

Finally, Eq. (2) was tested with data pertaining to sphere columns and corresponding monitoring locations (not shown herein). Overall, the analysis of data revealed that the three-

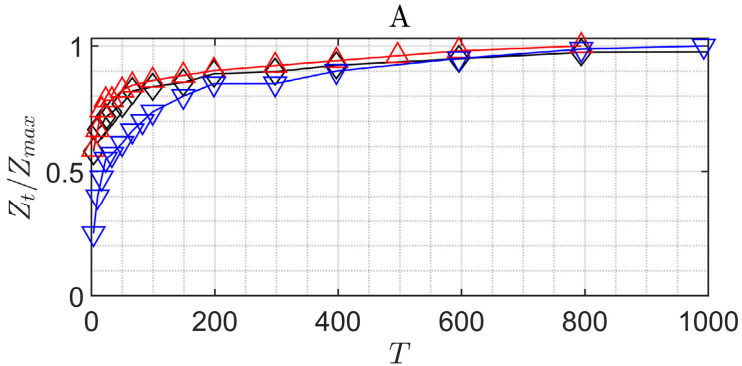

B

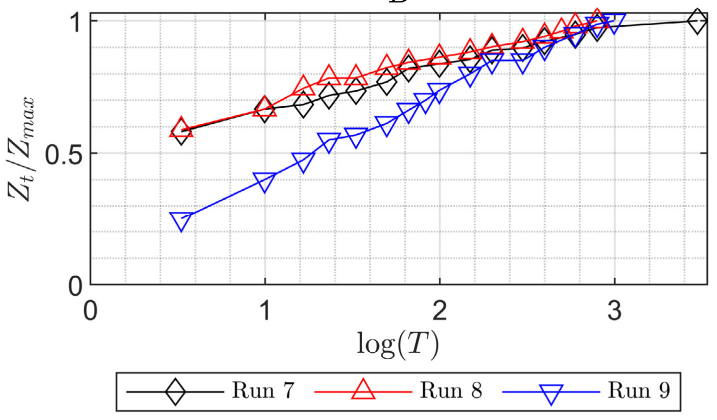

Fig. 10. $Z_{t} / Z_{\max }$ as function of (A) $T$ and (B) $\log (\mathrm{T})$ for Substrate 1, tests $7 \mathrm{R}, 8 \mathrm{R}$, and 9 .

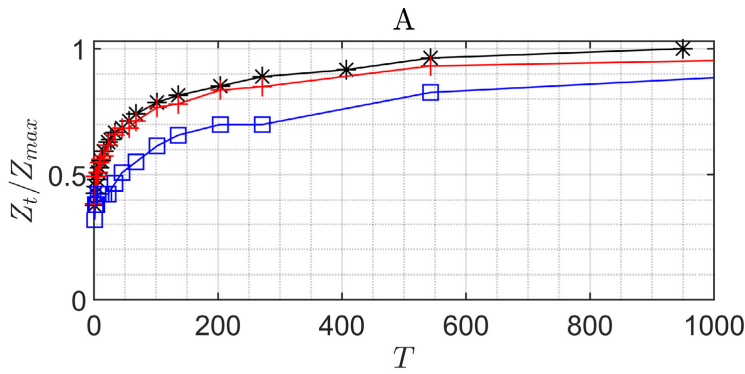

$\mathrm{B}$

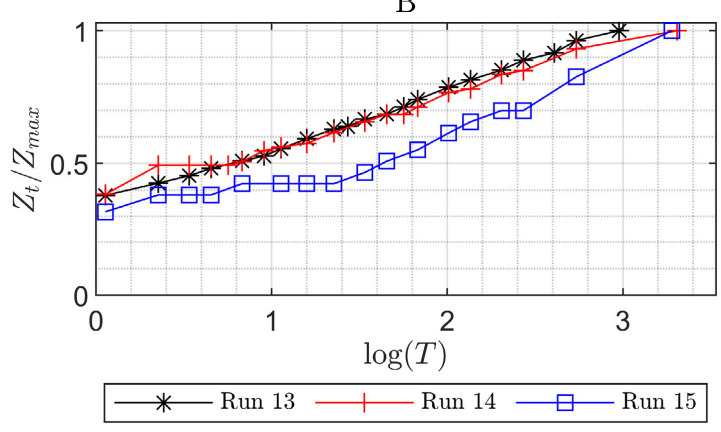

Fig. 11. $Z_{t} / Z_{\max }$ as function of (A) $T$ and (B) $\log (\mathrm{T})$ for Substrate 2, tests 13,14 , and 15 .

dimensional scour evolution is consistent with that shown above. Therefore, it is concluded that the evolution process evolves homothetically downstream of a PK weir and Eq. (3) represents a reliable tool to predict scour evolution at the location $X_{\max }$ of the maximum scour depth $Z_{\max }$.

\section{Scour depth at equilibrium}

In this section, the predicting capability of several wellknown approaches developed for other grade control structures is tested, including PK weir specific Jüstrich et al. (2016). To this end, empirical equations proposed by Mason and Arumugam (1985), Bormann and Julien (1991), Jüstrich et al. (2016) and Ben Meftah and Mossa (2020) were selected. 

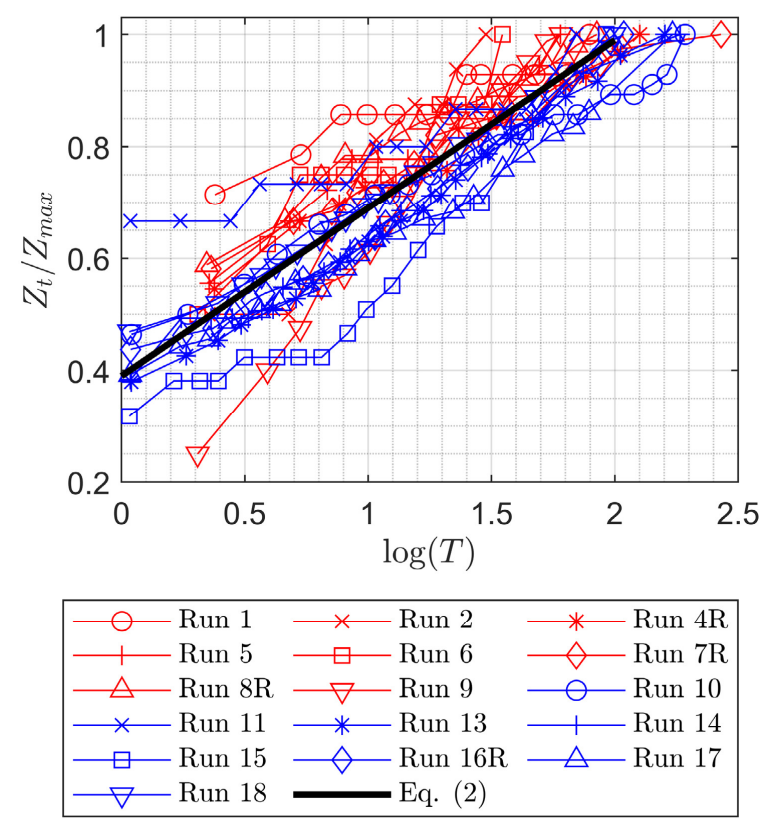

Fig. 12. $Z_{t} / Z_{\max }$ as function of $\log (T)$ for all conducted tests.

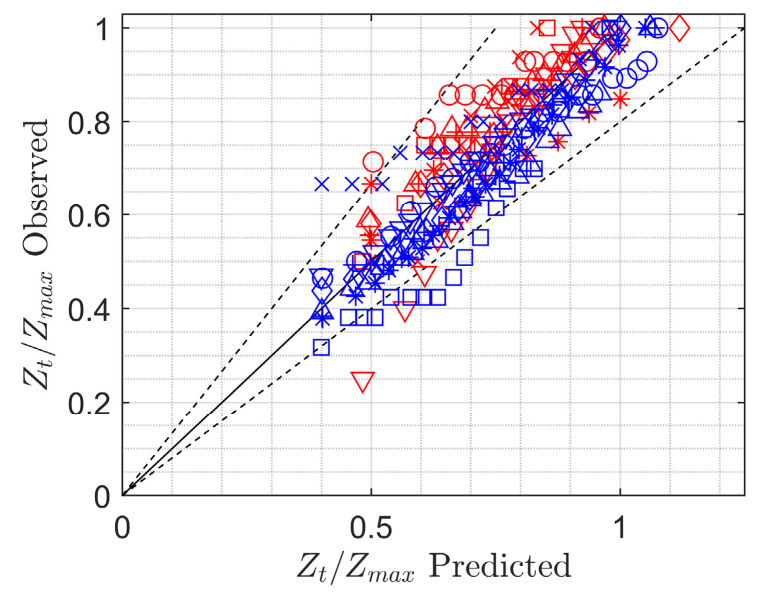

$\begin{array}{llllll}\bigcirc & \text { Run 1 } & \times & \text { Run 2 } & * & \text { Run 4R } \\ + & \text { Run 5 } & \square & \text { Run 6 } & \diamond & \text { Run 7R } \\ \triangle & \text { Run 8R } & \nabla & \text { Run } 9 & \bigcirc & \text { Run 10 } \\ \times & \text { Run 11 } & * & \text { Run 13 } & + & \text { Run 14 } \\ \square & \text { Run 15 } & \diamond & \text { Run 16R } & \triangle & \text { Run 17 } \\ \nabla & \text { Run 18 } & \ldots-\ldots & \text { 25\% Deviation } & & \end{array}$

Fig. 13. Comparison between observed and predicted (using Eq. (2)) values of the parameter $Z_{t} / Z_{\max }$.

Mason and Arumugam (1985) investigated the scour mechanism caused by free overfalls, low level outlets, spillway flip buckets, and tunnel outlets. Based on laboratory results, they derived the following equation:

$Z_{\text {max }}+h_{d}=\frac{K q^{a_{m}} \Delta H^{c} h_{d}^{e}}{g^{k} d_{50}^{n}}$

where the coefficient $K=6.42-3.1 \Delta H^{0.1}, a_{m}=0.6-\Delta H / 300$, $c=0.15+\Delta H / 200, e=0.15, k=0.3$, and $n=0.1$.

Likewise, Bormann and Julien (1991) investigated the scour occurring downstream of grade-control structures. They developed a semi-theoretical approach based on the jet diffusion theory in a turbulent cauldron. Experimental evidence allowed the authors to derive the following expression for the estimation of the variable $Z_{\max }+P$ :

$$
Z_{\text {max }}+P=\frac{K_{b} q^{0.6} U_{j} \sin \theta}{(2 G g)^{0.8} d_{90}^{0.4}}
$$

where $P=$ drop height of the structure or weir height, $K_{b}=$ $1.8^{2}[\sin \phi / \sin (\phi+\theta)]^{0.8}, \theta=$ jet angle, $\phi=$ wet angle of repose of the bed material, jet velocity $U_{j}=(2 g \Delta H)^{0.5}$, and $g$ is the acceleration due to gravity.

Conversely, Jüstrich et al. (2016) analyzed scour process downstream of PK weirs, concluding that the relative maximum scour depth $Z_{\max } / d_{50}$ can be estimated as follows:

$$
\frac{Z_{\max }}{d_{50}}=0.42\left(\frac{h_{c}}{d_{50}}\right)^{1.7}\left(\frac{\Delta H}{h_{d}}\right)^{0.3}
$$

where $h_{c}=$ critical depth and $\Delta H=$ theoretical impact head (i.e., jet falling height) (m). Nevertheless, the model size of the PK weir used by Jüstrich et al. (2016) was approximately equal to $1 / 3$ than the current study. Therefore, the application of their methodology to present data can also provide useful insights on potential scale effects affecting the smaller model.

Finally, tested herein was the recent empirical equation developed by Ben Meftah and Mossa (2020) for various angled jets originating from grade control structures:

$$
\begin{aligned}
& \frac{Z_{\max }}{h_{u}}=0.24\left(1+\frac{P}{h_{u}}\right)^{0.92}\left(\frac{h_{d}}{h_{u}}\right)^{0.24}\left(\frac{\theta}{\pi}\right)^{-0.34}\left(F r^{*}\right)^{0.38} \\
& F r^{*}=\frac{q}{h_{u}\left[(G-1) g d_{50}\right]^{0.5}}
\end{aligned}
$$

where $\mathrm{Fr}^{*}$ is the densimetric Froude number using $d_{50}$ as the characteristic particle diameter.

The resulting comparisons is presented in Fig. 14, which contrasts observed against predicted (using Eqs. (3)-(6)) values of $Z_{\max }$. For the PK weir data of the current study, it was found that Eqs. (3) and (5) perform better than others $\left(R^{2}=0.91\right.$ and 0.96 , respectively). Nonetheless, it is worth mentioning that the accuracy of Eq. (5) decreases for lower values of $Q$ and higher values of $h_{d}$. This can be explained when considering that high relative submergence of the structure modifies jet diffusion in the pool immediately downstream of the PK weir. Therefore, further investigations are needed in this regard. Conversely, Eq. (3) appears to be more conservative than Eq. (5). Namely, experimental data are generally overestimated, especially for higher $Q$ and low $h_{d}$.

Apparently, equations derived for grade control structures, i.e., Eqs. (4) and (6), do not provide an accurate prediction of data pertaining to scour downstream of PK weirs. This result is unsurprising when considering that the scour mechanism characterizing low-head grade control structures exhibits different features from that characterizing jet-driven processes. Conversely, the scour evolution dynamics downstream of a PK weir are essentially similar to that characterizing plunging jets (see also previous section). The higher accuracy of the Eq. (3) proposed by Mason and Arumugam (1985) can be explained considering that it has been validated with data pertaining to scour caused by free overfalls under hydraulic conditions that are consistent with those of the present study. Overall, this comparative analysis revealed that even specific formulas (Eq. 5) are 


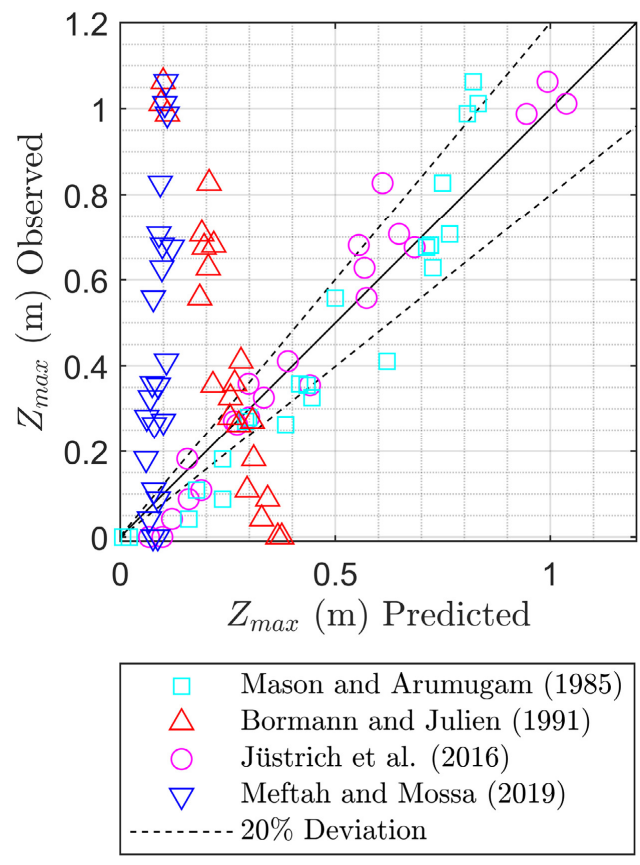

Fig. 14. Comparison of observed and predicted (using other authors' equations, Eqs. (3)-(6) herein) values of $Z_{\max }$.

subjected to some limitations. Namely, they can provide reliable results only in the tested range of parameters and their accuracy is affected by hydraulic conditions. Following recent advancements in the theoretical modeling of scour mechanism caused by plunging jets (Bombardelli et al., 2018), it is believed that the aforementioned mentioned shortcomings could be overcome by a first principle-based approach that does not depend on tested conditions nor is limited by scale effects.

\section{APPLICATIVE EXAMPLE}

Assuming from analyses and field study of a proposed PK weir $\left(P=0.419 \mathrm{~m}\right.$ and $\left.L_{c}=10.17 \mathrm{~m}\right)$ located in a channel, the noncohesive riverbed material is $d_{50}=0.0065 \mathrm{~m}$ and $d_{90}=$ $0.0091 \mathrm{~m}, G=2.65$ and $\rho_{s}=2,646 \mathrm{~kg} / \mathrm{m}^{3}$, the unit discharge of interest is $q=0.30 \mathrm{~m}^{2} / \mathrm{s}$. Corresponding hydraulic conditions were calculated to be: $h_{c}=0.20 \mathrm{~m}, h_{d}=0.43 \mathrm{~m}$ with $g=9.81$ $\mathrm{m} / \mathrm{s}^{2} . \Delta H=0.25 \mathrm{~m}$ can be estimated using a head-discharge rating curve with corresponding $H$ and energy dissipation from Eslinger and Crookston (2020). As discussed herein, the majority of scour would be expected to occur in Phase 1, thus for sufficiently long durations of flow, a maximum scour depth can conservatively be assumed. $Z_{\max }$ may be estimated using Fig. 8 $\left(Z_{\max }=0.68 \mathrm{~m}\right)$ or Eq. (5) $\left(Z_{\max }=0.684\right)$. As noted in Fig. 8 and Table $4, X_{\max }$ and $L_{\max }$ can be estimated graphically at approximately $X_{\max }=1.0 \mathrm{~m}$ and $L_{\max }=2.0 \mathrm{~m}$. Referencing Fig. 14 and prediction deviations, $Z_{\max }$ may be adjusted as deemed appropriate by the engineer; for example, a factor of 1.2 would result in $Z_{\max } \sim 0.8 \mathrm{~m}$.

To consider the temporal evolution and time required to reach a $Z_{\max }=0.68 \mathrm{~m}$ (e.g., considering a flow hydrograph with time duration corresponding to $q$ ), Eq. (2) can be applied with $\xi$ $=0.594$ computed for this example and Eq. (1b) (note that $t$ must be in seconds); this is illustrated in Table 5. As shown, within 5 minutes approximately $60 \%$ of the maximum scour depth has been reached. If a longer $3 \mathrm{hr}$ duration occurred, $Z_{t}$ is within $85 \%$ of $Z_{\max }$. Thus, this methodology allows a practitioner to consider not only the maximum scour hole geometry, but also the temporal evolution and corresponding phases.
Table 5. Example calculation for $Z_{t}$.

\begin{tabular}{llll}
\hline $\begin{array}{l}t \\
(\mathrm{~s} / \mathrm{min})\end{array}$ & $T$ & $\log (T)$ & $\begin{array}{l}Z_{t} \\
(\mathrm{~m})\end{array}$ \\
\hline $300 / 5$ & 11.3 & 1.05 & 0.40 \\
$1,800 / 30$ & 67.8 & 1.83 & 0.49 \\
$3,600 / 60$ & 135.7 & 2.13 & 0.53 \\
$7,200 / 120$ & 271.3 & 2.43 & 0.57 \\
$10,800 / 180$ & 407.0 & 2.61 & 0.59 \\
$61,200 / 1,020$ & $2,306.3$ & 3.36 & 0.68 \\
\hline
\end{tabular}

\section{CONCLUSIONS}

To summarize, local scour at nonlinear weirs is an understudied topic even with the growing popularity of the structure type. Furthermore, increased risk from climate change has made scour a popular research topic for both researchers and practitioners. It is concluded that under particular hydraulic conditions, scour at PK weirs can significantly exceed the $P$ of the structure itself. The intensity, depth, and evolution of the scour morphology is dependent on particle characteristics, $Q$, and $h_{d}$. A decrease in particle size and $h_{d}$ produces more scour, whereas an increase in $Q$ increases the amount of scour.

A combination of experimental observations and scour parameters were combined herein to estimate via a new method the time evolution of scour at a PK weir under various hydraulic conditions and maximum local scour depth (Eq. 2), the maximum scour depth location (Fig. 8), and maximum scour hole length (Fig. 8 and Table 4) at PK weirs.

A significant amount of previous research pertaining to scour at different structures has produced various prediction methods. A select few prediction methods were evaluated within the study. It has been determined that the PK weir specific Jüstrich et al. (2016) prediction method (Eq. 5 herein) was determined to be the most accurate and could estimate $Z_{\max }$ under various hydraulic conditions.

Different structures and projects have different geometric and geological properties, which can cause the amount of scour to vary considerably from published data and prediction methods. Performing a physical model study of proposed projects and simulating particular hydraulic conditions is the recommended approach to accurately understand the degree of scour that will occur.

Acknowledgements. For Mr. Lantz and Dr. Crookston, this study was funded by: the State of Utah through the Utah Water Research Laboratory; by a United States Geological Survey (USGS) 104B grant (2019UT256B); and by a donation from D.B. Campbell.

\section{Data availability statement}

Some or all data, models, or code that support the findings of this study are available from the corresponding author upon reasonable request.

\section{REFERENCES}

Aderibigbe, O., Rajaratnam, N., 1998. Effect of sediment gradation on erosion by plane turbulent wall jets. J. Hydraul. Eng., 124, 10, 1034-1042. DOI: 10.1061/(ASCE)07339429(1998)124:10(1034)

Adduce, C., Sciortino, G., 2006. Scour due to a horizontal turbulent jet: Numerical and experimental investigation. J. Hydraul. Res., 44, 5, 663-673. DOI: https://doi.org/10.1080/ 00221686.2006 .9521715 
Annandale, G.W., 1995. Erodibility. J. Hydraul. Res., 33, 4, 471-494. DOI: 10.1080/00221689509498656

Ben Meftah, M., Mossa, M., 2020. New approach to predicting local scour downstream of grade-control structure. J. Hydraul. Eng., 146, 2. DOI: 10.1061/(ASCE)HY.19437900.0001649

Bombardelli, F.A., Palermo, M., Pagliara, S., 2018. Temporal evolution of jet induced scour depth in cohesionless granular beds and the phenomenological theory of turbulence. Physics of Fluids, 30, 8, 085109. DOI: 10.1063/1.5041800

Bormann, N.E., Julien, P.Y., 1991. Scour downstream of gradecontrol structures. J. Hydraul. Eng., 117, 5, 579-594. DOI: 10.1061/(ASCE)0733-9429(1991)117:5(579)

Bung, D.B., Crookston, B.M., Valero, D., 2021. Turbulent freesurface monitoring with an RGB-D sensor: the hydraulic jump case. J. Hydraul. Res., 59, 779-790. DOI: 10.1080/00221686.2020.1844810

Center for Disaster Philanthropy, 2019. 2019 Catastrophic River Flooding. Center for Disaster Philanthropy. Accessed Jan. 25, 2020. https://disasterphilanthropy.org/disaster/2019u-s-spring-floods/

Chen, J., Hsu, H., Hong, Y., 2016. The influence of upstream slope on the local scour at drop structure. J. Mt. Sci., 13, 12, 2237-2248. DOI:10.1007/s11629-015-3790-5

Crookston, B.M., Erpicum, S., Tullis, B.P., Laugier, F., 2019. Hydraulics of labyrinth and piano key weirs: 100 years of prototype structures, advancements, and future research needs. J. Hydraul. Res., 145, 12, 02519004. DOI: 10.1061/(ASCE)HY.1943-7900.0001646

Dey, S., Sarkar, A., 2006. Scour downstream of an apron due to submerged horizontal jets. J. Hydraul. Eng., 132, 3, 246 257. DOI: https://doi.org/10.1061/(ASCE)0733-9429(2006) 132:3(246)

Dey, S., Raikar, R.V., 2007. Scour below a High Vertical Drop. J. Hydraul. Eng., 133, 5, 564-568. DOI: 10.1061/ (ASCE)0733-9429(2007)133:5(564)

Elnikhely, E.A., Fathy, I., 2020. Prediction of scour downstream of triangular labyrinth weirs. Alex. Eng. J., 59, 2, 1037-1047. DOI: 10.1016/j.aej.2020.03.025

Ervine, D.A., Falvey, H.T., Whiters, W., 1997. Pressure fluctuations on plunge pool floors. J. Hydraul. Res. 35, 257-279. DOI: https://doi.org/10.1080/00221689709498430

Eslinger, K., Crookston, B.M., 2020. Energy dissipation of Type A Piano Key Weirs. Water 2020, 12, 1253; DOI: 10.3390/w12051253

Ettema, R., Yoon, B., Nakato, T., Muste, M., 2004. A review of scour conditions and scour-estimation difficulties for bridge abutments. Water Eng., 8, 6, 643-650. DOI: 10.1007/ BF02823555

FloodList, 2020. Floods in USA. Accessed: Jan. 25, 2020. http://floodlist.com/america/usa

Gebhardt, M., Herbst, J., Merkel, J., Belzner, F., 2019. Sedimentation at labyrinth weirs - an experimental study of the self-cleaning process. J. Hydraul. Res., 57, 4, 579-590. DOI: $10.1080 / 00221686.2018 .1494053$

Green, C., 2010. Towards sustainable flood risk management. Int. J. Disaster Risk Sci., 1, 1, 33-43. DOI: 10.3974/j

Hoffmans, G.J.C.M., 1998. Jet scour in equilibrium phase. J. Hydr. Eng., 124, 4, 430-437. DOI: https://doi.org/10.1061/ (ASCE)0733-9429(1998)124:4(430)

Hoffmans, G.J.C.M., Verheij, H.J., 1997. Scour Manual. Balkema, Rotterbam, The Netherlands, 205 p.

Jia, Y., Kitamura, T., Wang, S.S.Y., 2001. Simulation of scour process in plunging pool of loose bed-material. J. Hydraul. Eng., 127, 3, 04016043, 219-229. DOI:
10.1061/(ASCE)0733-9429(2001)127:3(219)

Jüstrich, S., Pfister, M., Schleiss, A.J., 2016. Mobile riverbed scour downstream of a piano key weir. J. Hydraul. Eng., 142, 11, 04016043. DOI: 10.1061/(ASCE)HY.19437900.0001189

Kuhnle, R.A., Alonso, C.V., Shields, F.D., 2002. Local scour associated with angled spur dikes. J. Hydraul. Eng., 128, 12, 1087-1093. DOI: 10.1061/(ASCE)0733-9429(2002)128: $12(1087)$

Lantz, W., 2021. A laboratory study on the geometric effects of piano key weirs on scour for non-cohesive substrates and simple mitigation techniques. PhD Thesis. Utah State University, Logan, Utah. DOI: https://doi.org/10.26076/b3d7$379 d$

Lantz, W., Crookston, B.M., Palermo, M., 2020. Flood infrastructure: Localized scour at Piano Key Weirs. In: Conference Proceedings Dam Safety 2020. Association of State Dam Safety Officials, Lexington, KY, pp. 691-703.

López-Soto, J., Wibowo, J., Molina-Bas, O., 2016. Cost reduction in dam infrastructure using arced labyrinth spillways. In: Proc. Construction Research Congress 2016. San Juan, Puerto Rico, pp. 647-656. DOI: 10.1061/9780784479827.066

Machiels, O., Pirotton, M., Pierre, A., Dewals, B., Erpicum, S., 2014. Experimental parametric study and design of Piano Key Weirs. J. Hydraul. Res., 52, 3, 326-335. DOI: 10.1080/00221686.2013.875070

Marsooli, R., Lin, N., Emanuel, K., Feng, K., 2019. Climate change exacerbates hurricane flood hazards along US Atlantic and Gulf Coasts in spatially varying patterns. Nat. Commun., 10, 1, 3785. DOI: 10.1038/s41467-019-11755-Z

Mason, P.J., Arumugam, K., 1985. Free jet scour below dams and flip buckets. J. Hydraul. Eng., 111, 2, 220-235. DOI: 10.1061/(ASCE)0733-9429(1985)111:2(220)

Microsonic, 2021. mic $+130 / \mathrm{IU} / \mathrm{TC}$. mic + ultrasonic sensors. Accessed: Mar. 4, 2021. https:/www.microsonic.de/en/ distance-sensors/cylindrical/micplus/standard-sensors/stand ard-sensors/micplus130iutc.htm

Nasrollahi, A., Ghodsian, M., Neyshabour, S.A.A.S., 2008. Local scour at permeable spur dikes. J. Appl. Sci., 8, 19, 3398-3406. DOI: $10.3923 /$ jas.2008.3398.3406

NWS, 2020. NWS Preliminary US Flood Fatality Statistics. National Weather Service (NWS), National Oceanic and Atmospheric Administration (NOAA). Accessed: Jan. 25, 2020. https://www.weather.gov/arx/usflood

Noseda, M., Stojnic, I., Pfister, M., Schleiss, A.J., 2019. Upstream erosion and sediment passage at Piano Key Weirs. J. Hydraul. Eng., 145, 8, 04019029. DOI: 10.1061/(ASCE)HY.1943-7900.0001616

Oliveto, G., Hager, W.H., 2002. Temporal evolution of clear water pier and abutment scour. J. Hydraul. Eng., 128, 9, 811-820. DOI: https://doi.org/10.1061/(ASCE)0733-9429 (2002)128:9(811)

Pagliara, S., Amidei, M., Hager, W.H., 2008a. Hydraulics of 3D plunge pool scour. J. Hydraul. Eng., 134, 9, 1275-1284. DOI: 10.1061/(ASCE)0733-9429(2008)134:9(1275)

Pagliara, S., Hager, W.H., Unger, J., 2008b. Temporal evolution of plunge pool scour. J. Hydraul. Eng., 134, 11, 16301638. DOI: 10.1061/(ASCE)0733-9429(2008)134:11(1630)

Pagliara, S., Palermo, M., Carnacina, I., 2008c. Scour control and surface sediment distribution downstream of block ramps. J. Hydraul. Res., 46, 3, 334-343. DOI: 10.3826/jhr.2008.3208

Palermo, M., Bombardelli, F.A., Pagliara, S., 2018. From developing to developed phase in the scour evolution due to 
vertical and sub-vertical plunging jets: New experiments and theory. In: Proc. $7^{\text {th }}$ International Symposium on Hydraulic Structures. Aachen, Germany. DOI: 10.15142/T3ZH2Z

Palermo, M., Crookston, B., Pagliara, S., 2020. Analysis of equilibrium morphologies downstream of a PK Weir Structure. In: Proc. World Environmental and Water Resources Congress 2020. American Society of Civil Engineers (ASCE), pp. 43-51. DOI: 10.1061/9780784482971.005

Palermo, M., Pagliara, S. Roy, D., 2021. Effect of debris accumulation on scour evolution at bridge pier in bank proximity. J. Hydrol. Hydromech., 69, 3031, 1, 108-118. DOI: 10.2478/johh-2020-0041

Pfister, M., Jüstrich, S., Schleiss, A., 2017. Toe-scour formation at Piano Key Weirs. Labyrinth and Piano Key Weirs III - PKW 2017. Taylor and Francis Group, London, UK, pp. 147-156.

Schoklitsch, A., 1932. Kolkbildung unter Uberfallstrahlen. Wasserwirtschaft, 343.

Stein, O.R., Julien, P.J., Alonso, C.V., 1993. Mechanics of jet scour downstream of a headcut. J. Hydraul. Res., 31, 6, 723738. DOI: 10.1080/00221689309498814.

Wang, L., Melville, B.W., Whittaker, C.N., Guan, D., 2019. Scour estimation downstream of submerged weirs. J. Hydraul. Eng., 145, 12, 06019016. DOI: 10.1061/(ASCE)HY. 1943-7900.0001654.

Yazdi, A.M., Hoseini, S.A., Nazari, S., Amanian, N., 2021. Effects of weir geometry on scour development in the downstream of Piano Key Weirs. Water Supply, 21, 1, 289-298. DOI: $10.2166 /$ ws.2020.272.

Zhang, G., Valero, D., Bung, D.B., Chanson, H., 2018. On the estimation of free-surface turbulence using ultrasonic sensors. Flow Meas. Instrum., 60, 171-184. DOI: 10.1016/j.flowmeasinst.2018.02.009

\section{NOMENCLATURE}

The following symbols are used in this paper:

$a_{m}$ empirical coefficient in Mason and Arumugam (1985) method;

$B \quad$ depth of PK weir in streamwise direction (m);

$B_{b} \quad$ depth of PK weir base in streamwise direction (m);

$B_{i} \quad$ depth of PK weir inlet key overhang in streamwise direction $(\mathrm{m})$;

$B_{o} \quad$ depth of PK weir outlet key overhang in streamwise direction $(\mathrm{m})$;

c empirical coefficient in Mason and Arumugam (1985) method;

$d_{\mathrm{xx}} \quad$ material size for which $\mathrm{xx}$ percent of the material is finer (m);

$e \quad$ empirical coefficient in Mason and Arumugam (1985) method;

$\mathrm{Fr}^{*}$ densimetric Froude number;
$G \quad$ specific gravity of substrate material;

$g$ acceleration due to gravity $\left(\mathrm{m} / \mathrm{s}^{2}\right)$;

$H$ upstream total head (m);

$\Delta H$ change in upstream to downstream energy head (m);

$h_{c} \quad$ critical depth $(\mathrm{m})$;

$h_{d} \quad$ tailwater depth or piezometric head of water downstream of the weir (m);

$h_{u} \quad$ upstream headwater depth or piezometric head relative to the weir crest (m);

$K$ empirical coefficient in Mason and Arumugam (1985) method;

$K_{b} \quad$ empirical coefficient in Bormann and Julien (1991) method;

$k$ empirical coefficient in Mason and Arumugam (1985) method;

$L \quad$ scour hole length (m);

$L_{c} \quad$ weir crest length $(\mathrm{m})$;

$L_{\max }$ maximum scour hole length $(\mathrm{m})$;

$N$ number of PK weir cycles;

$n \quad$ empirical coefficient in Mason and Arumugam (1985) method;

$P \quad$ weir height (m);

$P_{d} \quad$ PK weir foundation height (m);

$Q \quad$ flow rate or volumetric discharge $\left(\mathrm{m}^{3} / \mathrm{s}\right.$ or $\left.\mathrm{L} / \mathrm{s}\right)$;

$q$ unit flow rate $\left(\mathrm{m}^{2} / \mathrm{s}\right)$;

$S_{i} \quad$ PK weir inlet key slope $(\mathrm{m} / \mathrm{m})$;

$S_{o} \quad$ PK weir outlet key slope $(\mathrm{m} / \mathrm{m})$;

$T$ nondimensional time;

$t$ time (min);

$t_{e} \quad$ time to equilibrium ( $\left.\mathrm{min}\right)$;

$t_{s} \quad$ weir wall thickness $(\mathrm{m})$;

$U_{j} \quad$ jet velocity $(\mathrm{m} / \mathrm{s})$;

$V \quad$ average flow velocity $(\mathrm{m} / \mathrm{s})$;

$W \quad$ flume width (m);

$W_{i} \quad$ PK weir inlet key width (m);

$W_{o} \quad$ PK weir outlet key width (m);

$W_{u} \quad$ PK weir cycle width (m);

$X \quad$ scour length in streamwise direction (m);

$X_{\max }$ maximum scour depth location along the $x$-axis (m);

$Z \quad$ scour depth (m);

$Z_{\max }$ maximum scour depth (m);

$Z_{t} \quad$ scour depth (m) at a particular time $t(\mathrm{~min})$;

$\alpha \quad$ labyrinth weir sidewall angle (in degrees);

$\xi \quad$ the temporal scour evolution parameter;

$\rho \quad$ density of water $\left(\mathrm{kg} / \mathrm{m}^{3}\right)$;

$\rho_{s} \quad$ density of substrate material $\left(\mathrm{kg} / \mathrm{m}^{3}\right)$;

$\sigma$ non-uniformity coefficient;

$\theta \quad$ jet angle (in degrees);

$\phi \quad$ wet angle of repose of substrate (in degrees); and

$\pi$ pi constant.
Received 28 May 2021 Accpted 15 October 2021 